\title{
COMMUNITY PARTICIPATION IN ENVIRONMENTAL DEVELOPMENT THROUGH SURABAYA GREEN AND CLEAN PROGRAM
}

Tiara Irawanti*, Meidyas Riska*, and Happy Ratna Santosa**

*) Master Student, Department of Architecture, Institut Teknologi Sepuluh Nopember, Indonesia

**) Department of Architecture, Institut Teknologi Sepuluh Nopember, Indonesia e-mail: meidyas36@gmail.com

\begin{abstract}
Neighbourhood unit (RW) 7 Simokerto Village, District Simokerto is one of the winners of Surabaya Green and Clean program $(S G C)$, which involves the participation of citizens in the development of environmentally related activities. The purpose of this study is to investigate the community participation in Neighbourhood unit (RW) 7 Kampung Simokerto in Surabaya Green and Clean program $(S G C)$. This research is a case study with the data collection methods of observation, interviews, and documentation. The results showed that community participation in the development of environmentally activities include voluntary work, planting and care of plants, organic and inorganic waste separation, use Takakura and composter, composting, waste bank procurement, and use of processed water from water treatment (IPAL) for watering plants thus saving the use of clean water.
\end{abstract}

Keywords: community participation, development of environment, green and clean

\begin{abstract}
ABSTRAK
RW 7 Kampung Simokerto, Kelurahan Simokerto adalah salah satu pemenang program Surabaya Green and Clean (SGC) yang melibatkan partisipasi masyarakat dalam pengembangan aktivitas yang terkait lingkungan hidup. Tujuan studi ini adalah untuk mengamati keterlibatan masyarakat di RW 7 Kampung Simokerto dalam program Surabaya Green and Clean (SGC). Hasil penelitian menunjukkan bahwa keterlibatan masyarakat dalam pengembang-an aktivitas yang terkait lingkungan hidup melibatkan kerja bakti, penanaman dan perawatan tanaman, pemisahan sampah organic dan anorganik, pemakaian Takakura dan komposter, komposting, usaha perolehan bank sampah, dan penggunaan air olahan dari IPAL untuk menyiram tanaman yang dapat menghemat penggunaan air bersih.
\end{abstract}

Kata kunci: partisipasi masyarakat, pembangunan lingkungan, Green and Clean 


\section{INTRODUCTION}

Along with the economic growth in urban area, demand for land continues to increase for the development of education, advance technology, city public facilities, transportation, public housing, and industry. One of the important issues facing economic development is how to deal with the trade-off between the needs of development on one hand and maintaining sustainable environment on the other hand (Jaya, 2004).

Economic development that is not environmentally sustainable will ultimately have a negative impact on the environment, because the natural resources and the environment have a limited carrying capacity. So as to maintain environmental sustainability, economic development must consider the carrying capacity of the environment or commonly referred to as sustainable development.

Sustainable city is certainly related to the condition of housing and settlements in it. Housing is one a particular aspect of sustainable development. One form of sustainable development in the city is the environmentally sound development. Government of Surabaya is seeking urban governance by using the principles of environmentally sound development. Green Kampung or Surabaya Green and Clean (SGC) is one of Surabaya municipality programs to create clean and healthy housing and residential environment. Environmental management programs involve the community as much as possible directly. Community participation is considered very important since the outcome of development is to improve the welfare of the community itself.

Surabaya Green and Clean program (SGC) is a flagship program of Surabaya municipality in order to create a clean and healthy environment. The program is joined by all districts in Surabaya. Some of the categories contested are: the most motivational kampung, flowering kampung, kampung with the role of active citizens (community participation), and kampung with the best water treatment (IPAL). One of the award-winning region in Surabaya Green and Clean (SGC) is neighbourhood (RW) 7 Kampung Simokerto, District Simokerto.

Urban land in Simokerto is very limited but people expect the environment to remain well preserved. These limitations make them take advantage of existing land by transforming it into green surroundings, starting from each household to plant a variety of plants such as ornamental plants and productive plants in the yard, fence and curb in front of their homes. In addition, they treat domestic waste to be recycled so that it can be used for various purposes, i.e. compost and handicrafts.

\section{THEORY / RESEARCH METHODS}

\section{Sustainable Development}

There are some meanings of sustainable development. Triwahyuni (2011) defines sustainable development is a concept that aims to create a balance between development dimensions, such as economic, social and environmental.

Other definitions regarding sustainable development, including: 
1. Brundtland Report of the United Nations (1987) which mentioned that one factor that must be overcome to achieve sustainable development is how to improve the environmental destruction without compromising the needs of economic development and social justice.

2. Report of the 2005 World Summit, which describes sustainable development as consisting of three main pillars (economic, social, and environmental) that are interdependent and reinforcing.

3. Universal Declaration on Cultural Diversity (UNESCO, 2001) which further explored the concept of sustainable development by stating that "... cultural diversity is important for humans as well as the importance of biodiversity for nature". Thus "development is not only understood as economic development, but also as a means to achieve the satisfaction of intellectual, emotional, moral, and spiritual". In this view, cultural diversity is the fourth policy of sustainable development policy

According to the various definitions of sustainable development, we can conclude that sustainable development is an effort in development that includes economic, social, and even cultural environment to meet the needs of the present without compromising or reducing the chance of future generations to enjoy and use the resources.

\section{Sustainable Development Concept}

The concept of sustainability can be specified into three aspects of understanding, that is:

1. Economic sustainability is defined as development that is able to produce goods and services continuously to maintain continuity of government and avoid sectoral imbalances that can damage agricultural and industrial production.

2. Environment sustainability (ecology): The system must be environmentally sustainable that are able to maintain a stable, avoiding the exploitation of natural resources and environmental functions of absorption. This concept also involves the maintenance of biological diversity, the stability of the air, and other ecosystem functions that are not included in economic resources category.

3. Social sustainability, social sustainability is defined as a system that is capable of achieving equality, providing social services including health, education, gender, and political accountability (Haris in Dewi, 2011).

In line with the above concept, Sutamihardja (in Jaya, 2004), stated sustainable development goals include in an effort to realize the occurrence of:

1. Intergeneration equity which means that the use of natural resources for the benefit of growth needs to pay attention to the limits of the reasonable control of the ecosystem or environmental systems and natural resources are geared towards emphasizing the lowest possible replaceable and exploitation of natural resources irreplaceable. 
2. Safeguarding or protection of natural resources and the environment of existing and prevention of ecosystem disruptions in order to ensure a good quality of life that remain for generations to come.

3. Utilization and management of natural resources for the benefit solely in the interest of pursuing economic growth equalization sustainable use of natural resources between generations.

4. Maintaining society welfare sustained both in present and future periods (intertemporal).

5. Maintaining the benefits of development or natural resource management and environment that have impacts or long-term sustainable benefits between generations.

6. Maintaining the quality of human life across generations according to their habitat.

\section{Community Based Management}

According to Budi (2004), community-based natural resource management is one approach to natural resource management that put the knowledge and awareness of local communities as a basis for management. In this management system people are given the opportunity and responsibility to manage the resources they have, where people themselves defined the needs, goals and aspirations, as well as making decisions for their welfare.

Environmental management is an important effort in maintaining the balance of resource. This means that not only the current generation can enjoy numerous resources, but also the future generations.

The community-based management (CBM) fully manage the planning stage to the supervision carried out by members of the community through organizations that are informal. This model shows the active participation of the community and they have autonomy over the management of their own resources (Satria, 2002).

\section{Community Participation}

Participation is the active involvement of communities in decision-making, implementation, utilization and evaluation results (Cohen and Uphoff, 1977). Understanding other participation defined by Sajogyo (1998) as an opportunity to participate in determining the development policy as well as the opportunities come assess development results. In general, participation is the active involvement of a person in an activity.

\section{Research methods}

This study used a qualitative method through case study research design. The research location is neighbourhood unit (RW) 7 of Simokerto Village, Simokerto District, Surabaya. In this research study, the subjects were environmental cadres, and citizen of neighbourhood unit 7 Simokerto. 
The techniques of data collection used were observation, interviews, and documentation. As for the analytical technique used is a descriptive qualitative analysis technique.

\section{RESULTS AND DISCUSSION}

\section{Environmental Condition}

Kampung Simokerto is administratively and geographically located in District Simokerto Surabaya. Simokerto Village consists of 16 Neighbourhood Units (RW) with an area of approximately $86 \mathrm{Ha}$. The area is the site of the study is the Neighbourhood Unit (RW) 7 Simokerto Village (see Figure 1).

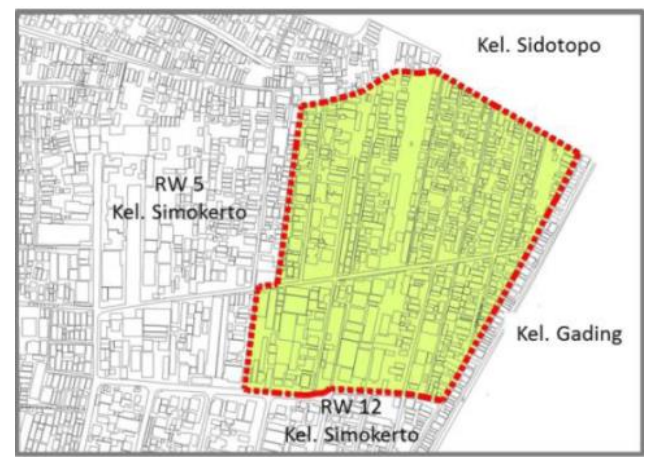

Figure 1. Study Area Source: Author's Documentation

Neighbourhood Unit (RW) 7 Simokerto Village is geographically located at an altitude of \pm 1.5 meters above sea level. Neighbourhood Unit 7 consists of 6 regions of RT. Most of the population has a living as a trader.

In Neighbourhood Unit (RW) 7 there are 2 RT representing Surabaya Green and Clean program (SGC), namely RT 1 and RT 3. However, public participation in the creation of a clean and healthy environment is done in each RT. As many other settlements in major cities in Indonesia which has a relatively high population density, Kampung Simokerto is also a dense settlement.

Based on observations along the alley, there are many types of plants that are well maintained. The plants are watered regularly, and not used as a landfill. In addition, there are a lot of shading trees, creating shady and green impression. Similarly, the condition of roads in the study area is not only paved but also painted with colours that added the aesthetic value.

\section{Community Participation in Environmental Development}

Neighbourhood Unit 7 Simokerto took part in Surabaya Green and Clean (SGC) program in 2012 and won for the growing category. The award for the first winner is 
water treatment for wastewater from PJB (Pembangkitan Jawa Bali). Success in wastewater treatment is not only naming Simokerto as clean and healthy but also the city of Surabaya.

Surabaya Green and Clean program (SGC) in RW 7 Simokerto took place in a gradual process. The first step was cleaning up the trash generated by people in the kampung. The division of duties is imposed by giving task for the women to put the waste into the trash that will be disposed of by the men subsequently using cart bins. The men served to paint the flower pots along the alley way, and painting the alley street with colours. Cleaning up the environmental is routinely conducted twice a month.

Every house in neighbourhood unit 7 Simokerto has bins placed in front of the house. Household waste generated was dumped into the trash and then transported by a waste hauler for disposal worker to conduct the final disposal.

However, there are some people who have done the sorting of organic and non-organic waste. Organic wastes are dumped into the composter and Takakura. Compost resulted from the composter and Takakura can be used by residents. As for non-organic waste such as plastic bottles, paper that has not been used, and others, they are collected and sold to scavengers. Even so, there are some people who keep their money from the selling and save it in neighbour unit's cash, and the money is used for consumption purposes when they have communal activities.

Composter is a tool used to help work of degrading bacteria (decomposer) in the form of various organic materials and waste into a new form: the compost material with properties like soil. With the decomposition, elemental carbon (C) and compounds in living things is returned to the soil. Decomposition was due to the work of beneficial bacteria (saprophyte) in a favourable microenvironment conditions.

Composter can be made from a used barrel, plastic barrel, basket of fruit, or piles of bricks arranged like a water container or directly created by drilling holes in the ground directly. Waste that can be composted organic waste that is derived from animals or plants such as kitchen waste, leftover vegetables, fruits, leftover food, fish bones, chicken bones, and fresh garden waste.

Waste processing before it goes into the composter includes chopping the waste into pieces small pieces to accelerate decomposition. The steps are preparing materials such as leaf plants, fresh cow dung, and soil gutter, then mixing all the ingredients in the water (water and material composition adjusted), crushing the leaf mixing, brown sugar or molasses, stirring, and covering the container tightly. After four days, this material can be used. Take 1 cup of starter compost (decomposing microorganisms) mixed with one litre of water then pour on the compost material that has been created in 3 days. Compost can be harvested after 30 days for garbage that is on the bottom. Meanwhile, pile new garbage on the top of the previous left part so on. The result of this composter is compost that can be harvested for 3-6 months. Figure 2 shows an example of a composter that is in the study area.

Takakura is a household composting appliance that is developed by Pusdakota Surabaya, Kitakyushu International Techno-cooperative Association, and the Kitakyushu Government of Japan in 2005 (see Figure 3). These baskets are assembled from simple materials around us are able to accelerate the composting process. 


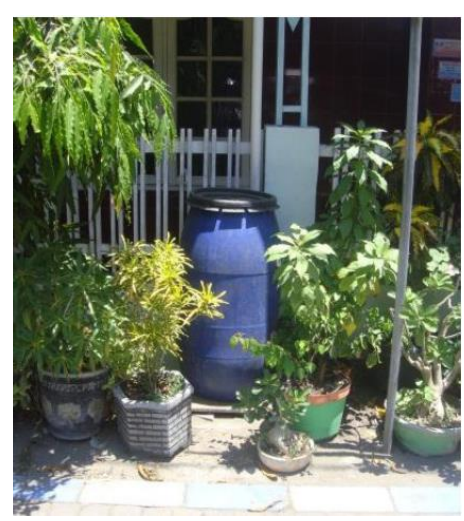

Figure 2. The Example of A Composter in The Study Area Source: field survey

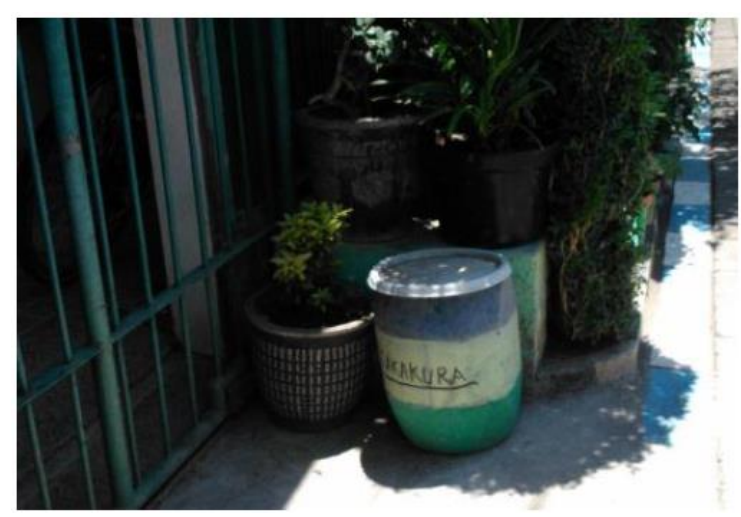

Figure 3. The Example of Takakura in Study Area Source: field survey

The standard basket with $8 \mathrm{~kg}$ of starter is used by families with a total family of 7 people. Household waste is processed in this basket a maximum of $1.5 \mathrm{~kg}$ per day. Here are the stages of processing waste with the help of Takakura baskets that can be used as fertilizer (see Figure 4).

Beside sewage treatment, other effort of citizens to keep the environment is conducting urban farming. Limited land did not discourage the spirit of citizens to build environmentally sound kampung, although in a small scale. The location of urban farming is not far from the location of the IPAL (water treatment), so for watering plants they use processed water from IPAL that will conserve water and energy efficiently. 


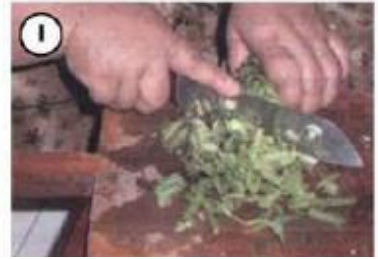

Chopped vegetable garbage before being put into the basket

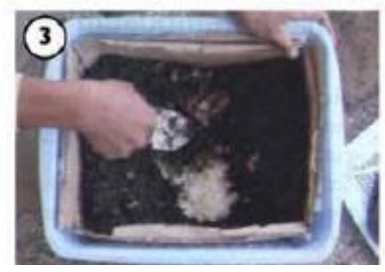

Press or put the garbage to the compost material in the basket or stir up until the garbage is covered by compost

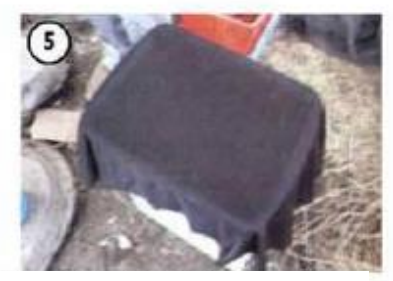

Cover with black cloth

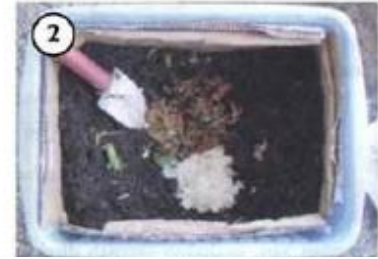

Put the leftovers into the basket, try to put fresh garbage

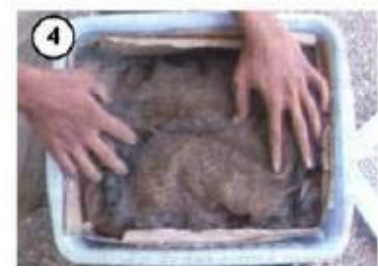

Cover with husk tightly to prevent flies and the other animal enter

Figure 4. The Process of Composting with Takakura Source: Pusdakota Surabaya

The working process of IPAL starts from sewer water -- which comes from domestic wastewater - flowed into the catchment tank that has been fitted with a filter at the bottom. Trash will be filtered and the water will flow into the space below. If the water contains sand, the sand will settle at the bottom of the chamber, while the layer of oil as lighter specific gravity will float in grease catcher. Water that has been free of sand, trash, and grease will flow into the pipes. The bottom of the pipe is given holes so that water will come out from the bottom. Before heading to the sewer water, the water will pass through the filter. The treated wastewater will be used for watering plants in the kampung (see Figure 5).

Efforts of RW 7 Simokerto of caring their environment cannot be separated from the role of environmental cadres. The cadres provide counselling about the importance of keeping the environment clean. Counselling is delivered through lectures or social gatherings. Figure 6 shows the schematic cadres role in enabling community to care about the environment. 


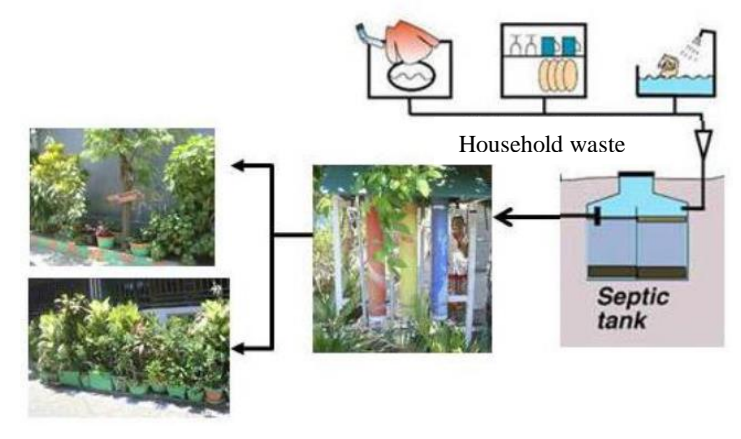

Figure 5. The Working of IPAL Source: Field Survey

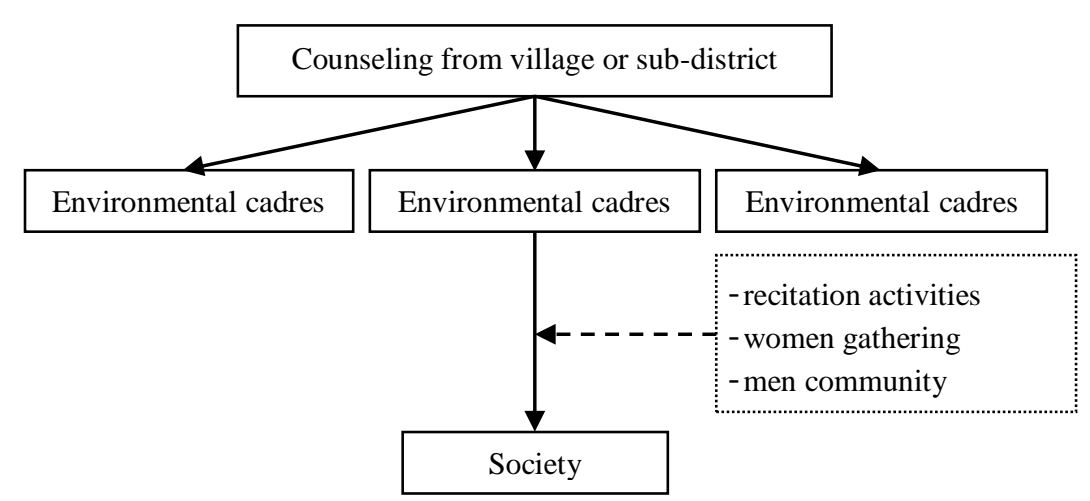

Figure 6. The Schematic of Cadre's Role in Enabling Community Source: Field Survey

Various activities were present at the initiation of environmental volunteers where they demonstrated their success in doing dissemination of innovation. Dissemination of innovations is the process of spreading innovations planned, directing, and managing. All activities originated from the ideas of residents and neighbourhood volunteers who later become a program run based on the volunteer's own environment. A series of activities undertaken by people starts from awareness to adoption of innovation (implementation). All activities were carried out in a period of time and there is a possible change at any time.

Albert Bandura (in Hergenhahn, 2009) mentions the role of others who provide exemplary or modelling for a person to later be replicated. Someone make observations and conduct an assessment of the behaviour of a model and then do the imitation or repetition of him. Assessment carried out there will relate to whether the benefits can be obtained or not from the mimicking process. In this case, the environmental cadres become a model for other people to carry out the Clean and Healthy Kampung Program.

With a retained value, participatory environmental care by residents of Neighbourhood Unit 7 Simokerto proves that there has been the internalization of environmental awareness within the community. Internalization of environmental 
care is carried out through a vigorous socialization carried out by the environment cadres so that it becomes a habit for residents of Neighbourhood Unit 7 Simokerto. This condition is favoured since they felt positive effects of changes in environmental conditions such as comfort, better health, and increase in economic standpoint.

\section{CONCLUSIONS}

Community participation of Neighbourhood Unit 7 Simokerto has been going well and should be maintained. Neighbourhood Unit 7 Simokerto won Surabaya Green and Clean (SGC) in 2012 for growing category and in 2013 for advance category with the best water treatment program (IPAL). The forms of participation in environmentally sound development in the Neighbourhood Unit 7 Simokerto are service activities, planting and maintenance of plants, organic and inorganic waste sorting and processing using Takakura and composter, waste bank procurement, and the use of processed water (IPAL) for watering plants, thus saving the use of clean water.

\section{REFERENCES}

(2012), Urban Deprivation: A Challenge to Sustainable Urban Settements, Proceeding Tropical eco Settlement.

Budi, D. S. (2004), Pengelolaan Sumberdaya Alam Berbasis Masyarakat, CIDA, Canada.

Cohen and Uphoff (1977), Rural Development: Concept and Measures for ProjectDesign, Implementation, and Evaluation, Cornel University, New York.

Hergenhahn, B. R. and Olson, M. H. (2009), Theories Learning (Teori Belajar). Kencana Prenada Media Group, Jakarta.

Jaya, A. (2004), Konsep Pembangunan Berkelanjutan (Sustainable Development), Bogor.

Satria, A. (2002), Pengantar Sosiologi Masyarakat Pesisir, PT Cidesindo, Jakarta.

Sajogyo (1998), Menuju Kemandirian Masyarakat, Prisma, 1, Tahun XVII, LP3ES, Jakarta. 